\title{
What Can be done by Value Creation in SMEs?
}

\author{
Reminta Lumban Batu, Eeng Ahman, Lili Adi Wibowo \\ Business Management Master Study Program \\ Universitas Pendidikan Indonesia \\ remi.lumbanbatu@gmail.com
}

\begin{abstract}
SMEs is essential for supporting business growth and can contribute to the growth of the economy. Value creation in accordance with the cultural values applied in Purwakarta SMEs to improve marketing performance. More and more SMEs have value creation in its operational activities will increasingly affect marketing performance of SMEs. This research is to analyze the data and information of value creation and marketing performance of SMEs Purwakarta. This study is descriptive verification method and cross sectional method for collecting primary data in the form of the questionnaire then verified by a research model with Partial Least Square. Value Creation has a positive effect capable of affecting the performance of marketing. This studies demonstrated that the implications of the use value creation to increased marketing performance.
\end{abstract}

\section{Keywords: value creation, marketing performance}

\section{INTRODUCTION}

Sustainability of SMEs is essential for supporting the growth of big business and can provide benefits for regional economic growth [1]. SMEs continue to look for ways to survive, grow, and compete in the market [2]. Competitiveness of SMEs in an economy affect the position of SMEs for the state of the country internationally. Research in several countries such as Italy, Palestine, and Tanzania showed that SMEs are still having problems, lack of competitiveness [3, 4, 5]. These problems occur in MSME Indonesia [6, 7].

The low competitiveness owned SMEs may result in a decrease in performance marketing. Improved marketing performance is indispensable in the development of the industry, including the development of creative industries [8]. Good marketing performance and increasing contribute to demonstrate the company's overall performance which can also be achieved through competitiveness. The ability of the company's competitiveness in the face of competition will affect the performance of the company's marketing [9]. Increasing competitiveness are expected to participate are able to provide the impact that improved marketing performance [3, 4].

Application of value creation in order to improve the business activities carried out as a strategy in corporate and business level $[10,11,12]$. Application of value creation that focuses on internal resources owned is also related to the competitiveness strategy in improving the competitiveness of companies [13].

Local value creation may be one innovative way for companies to compete [14]. Competitiveness strategies that create value proposed by Porter rated enhanced competitiveness and performance (the performance of companies) [15] and are able to influence the development of the economy[16]. Based on these explanations, the implementation of value creation Purwakarta district is considered to be one solution to increase marketing performance as part of the company's performance.

\section{LITERATURE REVIEW}

VALUE CREATION AS A MARKETING STRATEGY PERFORMANCE IMPROVEMENT

Marketing as one of the functional needs of an effective strategy to be designed and then implemented in the company's activities. Marketing is a process that is done by the company to build and create value for customers aiming to build strong relationships with customers and gain value from the customer itself to companies as a reply [17].

Strategic marketing done through market driven strategies that have four characters are becoming market oriented, determining distinctive capabilities, matching customer value requirements to capabilities, and delivering superior customer value. The strategy is done by doing a comparison which then adjusts the resources owned by the company in accordance with market demand to generate superior value [18]. It directs competitive strategies applied by the company to a strategy that focuses on the market and after the adjustment of resources and the consumers' desire to do the right value creation.

The paradigm of the more popular ones to see and understand the competitive strategy has been based on the idea that the proper strategic [19]. Another definition suggests that competitive strategy is a strategy that could affect the development of SMEs [20]. Competitive strategy is the art of creating or exploiting the advantages of the most enduring and difficult for competitors to imitate. Competitive strategies produce competitive strengths. Mean different strength resulting in the value-added chains [18].

Value creation in strategic marketing are in a wide scope of one of them is value based marketing is a marketing concept that is oriented towards the acquisition of an increase in the value of the consumers on the consumption of goods or services. The basic principle of value creation in value based marketing deals with four important things to be the process that is [21]: 1) Marketing and shareholder value; 2) The shareholder valued approach; 3) The marketing value drivers; and 4) The Growth. Value creation within the scope of value 
based marketing shows that the focus of the value associated with customer relationships, and company are also described in the concept of CRM (Customer Relationship Management) as the value that customers receive and the value of the company thanks [18]. Managers should be able to see the corporation as a social and active embedded. Uncover potential value creation for all stakeholders [22].

Value stimuli that affect customer service received internal customer perceived value. Individual needs to have a significant influence in the exchange of services and the value of the process. However, little is known about the role of internal customer needs to create value [23].

The company's strategy has always aimed to produce the proper performance for the company. One of them is the performance marketing related to the volume of sales and sales growth rates are good and constantly improve. Performance marketing is a factor that is often used to measure the impact of the strategy applied by the company. The Company strives to implement. Determine the right strategy to achieve marketing performance as expected.

\section{VALUE CREATION}

Value creation is something that is offered by the company in carrying out the transformation process involving the customer jointly with the company making the creation of value [24]. The definition explains the creation of value is something that is offered by the that involves the customer with each other with the company value creation.

Value creation is made to exploit a valuable opportunity; companies need a value-creation skill. Marketers must first: 1) identify new customer benefits from views of customers; 2) utilize the core competencies of the business domain; 3) selecting and managing a business partner of a cooperative network. Based on this insight are aware of customer focus, the core competencies are a business domain, and is a collective network of business partners [17].

There is another literature that describes the creation of value by using three dimensions, namely core activities or products, innovation, and differentiation. Another literature suggests that information, physical product, innovative configuration of transactions, reconfiguration and integration of resources, capabilities, roles and relationships between suppliers, partners, and customers who become a dimension of value creation. Based on a review of the literature mentioned before, the researchers decided to combine several dimensions presented earlier and tailored to the needs of research that dimensions used in this study were: 1) the physical product, 2) innovation, and 3) the relationship to the partner.

\section{PERFORMANCE MARKETING}

Marketing performance can also be defined in practice as a discipline and measurement practices, learn from and improve marketing strategies and tactics from time to time.This definition indicates that the performance of the applied marketing company learning outcomes to improve marketing strategies.

Dimension's marketing performance can be a measure can be described with the outcomes is the implementation strategy of the company. Such as customer satisfaction, the success of new products, increase sales and profitability so that the measurement of marketing performance can use the unit sales, customer growth and turnover of customers , Dimensions listed marketing performance shows that marketing performance can be measured after the results of the marketing strategies implemented community can be met. Marketing performance can also be measured by three other dimensions, namely sales growth, customer growth and sales volume. Another research suggests about marketing performance dimensions are 1) sales; 2) market share; 3 ) profitability [25].

Based on the multiple dimensions of performance marketing is described by experts in the literature and has been mentioned before, the dimensions of marketing performance used in this study were 1) the volume of sales, 2) growth of customers, 3) market share (market share), and 4) an increase in profit.

\section{METHODOLOGY}

This study uses a strategic marketing approach, especially regarding competitiveness. This study establishes a value creation strategy as an independent variable. The dependent variable is the performance marketing. The population of this research is the SMEs that have value creation in Purwakarta by sampling using cluster sampling technique with Partial Least Square analysis.

\section{FINDINGS AND DISCUSSION}

\section{DESCRIPTION OF VALUE CREATION}

Overall variable value creation consists of physical products, product innovation and service as well as the relationship to the partner. Dimensions can know its position based on the scores obtained from the data summary, where the values are compared to the criteria of standard score obtained by calculating the ideal score (criterion) with the smallest score, so that through a standard score can be known continuum region showing the ideal of a variable region.

TABLE I. DESCRIPTION OF VALUe CREATION

\begin{tabular}{llllll}
\hline Number & Dimension & Total Score & Average Score & Ideal Score & $\%$ \\
\hline 1 & Physical Product & 1572 & 157,20 & 190 & $49,3 \%$ \\
2 & Product and service innovation & 947 & 157,83 & 190 & $29,7 \%$ \\
3 & Relationship with Partner & 669 & 167,25 & 190 & $21,0 \%$ \\
\hline Value Creation & 3188 & 159,40 & 570 & $100,0 \%$ \\
\hline
\end{tabular}


Table I explain about recapitulation score of dimensions that influence the formation of value creation. Dimensional obtain the highest score is the relationship with the partner (HM) with a percentage of $21.0 \%$ while the dimensions obtain the lowest score is a physical product $(\mathrm{PF})$ with a percentage of $49.3 \%$. Figure 4.4 is based on the value continuum of value creation that is the value of 3188 or with the percentage of $83.89 \%$ according to research data that is included in the high category means through the measurement results is known that the value creation variables studied physical dimensions of product research, product and service innovation, and relationships with user partners have gone well in this study.

\section{DESCRIPTION OF PERFORMANCE MARKETING}

Recapitulation marketing performance overview will provide information on how the performance of the overall marketing picture. Marketing performance dimensions consisting of an increase in sales volume, market share, number of customers, number of new customers, and the percentage of profit overall picture can be seen by looking at the picture of each dimension that no one had merged and the views of development per year over the last five years.

TABLE II. DESCRIPTION OF PERFORMANCE MARKETING

\begin{tabular}{|c|c|c|c|c|c|}
\hline \multicolumn{6}{|c|}{ PERFORMANCE MARKETING } \\
\hline & 2011 & 2012 & 2013 & 2014 & 2015 \\
\hline AVERAGE & $8,6 \%$ & $10,5 \%$ & $13,2 \%$ & $16,3 \%$ & $18,2 \%$ \\
\hline Max & $70,0 \%$ & $70,0 \%$ & $100,0 \%$ & $100,0 \%$ & $100,0 \%$ \\
\hline Min & $-10,0 \%$ & $-10,0 \%$ & $-10,0 \%$ & $0,0 \%$ & $-20,0 \%$ \\
\hline STD. DEV & $11,3 \%$ & $12,0 \%$ & $14,6 \%$ & $16,0 \%$ & $17,0 \%$ \\
\hline
\end{tabular}

Table II shows the average picture marketing performance continues to increase from year to year over the last five years. Baste each dimension and overall picture of marketing performance, it is known that the marketing performance of SMEs Purwakarta constantly increasing.

The findings related to marketing performance in this study explained that an increase marketing performance over the last five years is supported from the increased sales volume, market share, number of customers, number of new customers, and percentage of profits are also constantly increasing. Marketing performance as well shows the spread of data is large enough meaning in SMEs Purwakarta, there are SMEs with marketing performance is very low to truly high.

The results of this study demonstrated the following research model:

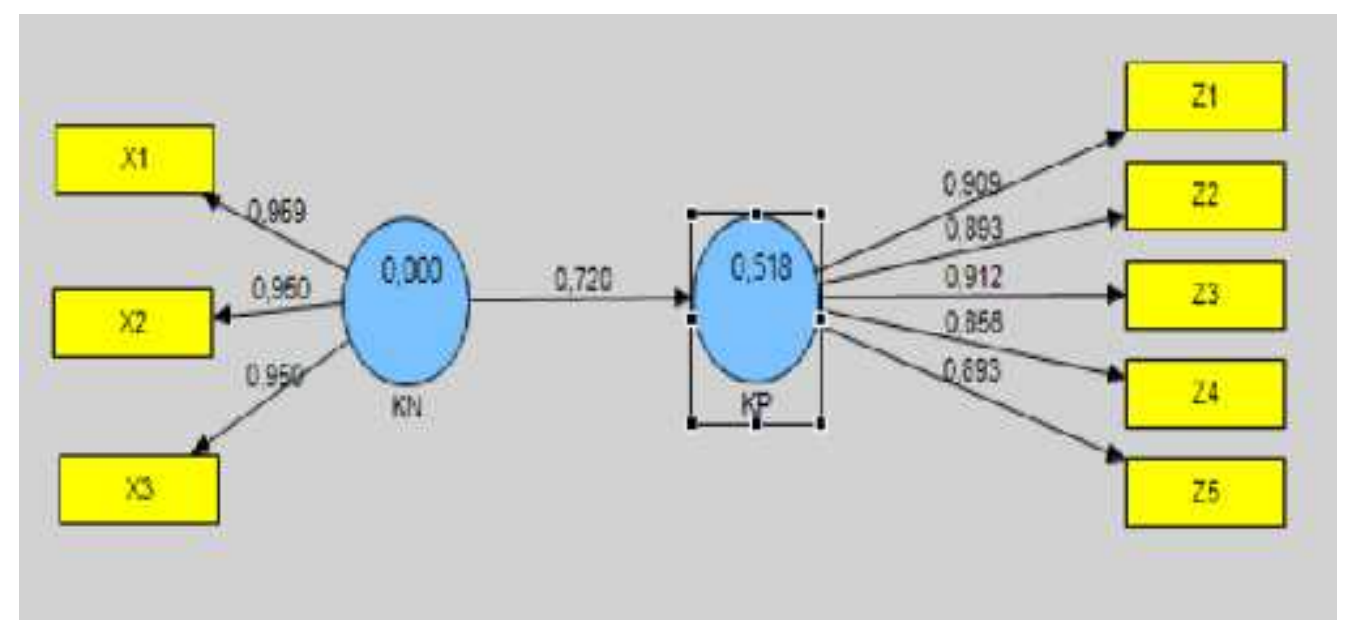

Fig. 1. Output PLS

Figure 1 shows the calculation results of research through the PLS model with SmartPLS application. The findings show that the creation of value $(\mathrm{X})$ of the endogenous latent variable marketing performance $(\mathrm{Z})$ of 0.720 with a positive means higher value creation $(\mathrm{X})$ can improve marketing performance (Z). Create positive effect on the value of marketing performance with the amount of $51.84 \%$ and amounted to $48.16 \%$ influenced by other factors. Based on these results can also be known that this research has implications for theories explaining variable value creation [13] can influence marketing performance.

These research findings are supported by previous studies on value creation are applied at Recreation Park Jakarta [26] which found that safety and ease of reaching a recreational park need to get the attention of the manager. While this study found that the factor of cultural values in the physical product and product and service innovation is highly considered by the owners of SMEs. 
Theories and concepts of marketing performance used in this study refers to the theory of marketing performance is done by applying the right strategies in practice resulting in an increase to advance marketing performance. Formulation of marketing performance dimensions refer to previous studies measuring the marketing performance.

\section{CONCLUSION}

This study shows that the creation of value owned by SMEs is one of the appropriate strategies to improve marketing performance. The study provides an overview of the information, and strategic marketing particularly value creation, competitiveness and performance of marketing adds to the knowledge of researchers. The number of limitations by the researchers produces hope that next researcher to conduct research with a more perfect. Based on these results, the researchers gave recommendations to the following researchers to investigate other variables are the possibilities to increase the competitiveness of SMEs and provide a good impact or increase marketing performance also for SMEs. Researchers further expected to do research better and reduce or even eliminate the existing limitations in this study for further research so that research can contribute better.

Relating to the competitiveness of SMEs Purwakarta, researchers also gave advice to SMEs more daring again to enter foreign markets so that in addition to expanding the controlled market but also a means of introduction of products and distinctive culture of Purwakarta internationally. Researchers also suggested that owners of SMEs are better able to read the conditions and tastes of the market in competing so that it can participate in providing input into future strategies like what is better to be established and applied in daily operational activities of SMEs Purwakarta.

\section{REFERENCES}

[1] Gilmore, Audrey, Entrepreneurial and SME marketing, Journal of Research in Marketing and Entrepreneurship, Vol. 13 Iss 2, 2007, pp. 137-145.

[2] Valkokari, Katri, Nina Helander, Knowledge management in different types of strategic SME networks, Management Research News, Vol. 30 Iss 8, 2007, pp. 597-608.

[3] Sami, Suhail, Enhancing the competitiveness of Palestinian SMEs through clustering", EuroMed Journal of Business, Vol. 9 Iss 2, 2014, pp. 164-174.

[4] Crick, David, Godwin E. Kaganda, Harry Matlay, A study into the international competitiveness of low and high intensity Tanzanian exporting SMEs, Journal of Small Business and Enterprise Development, Vol. 18 Iss 3, 2011, pp. 594-607.

[5] Kareev, Aleksandar, S.C. Lenny Koh Leslie T. Szamosi, The cluster approach and SME competitiveness: a review", Journal of Manufacturing Technology Management, Vol. 18 Iss 7, 2007, pp.818835
[6] Tambunan, Tulus, Development of small and medium enterprises in a developing country, Journal of Enterprising Communities: People and Places in the Global Economy, Vol. 5 Iss 1, 2011, pp. 68 - 82.

[7] Najib, Mukhamad, Akira Kiminami, Innovation, cooperation and business performance, Journal of Agribusiness in Developing and Emerging Economies, Vol. 1 Iss 1, 2011, pp. 75 - 96.

[8] HENDRAYATI, Heny; GAFFAR, Vanessa. Innovation and Marketing Performance of Womenpreneur in Fashion Industry in Indonesia. Procedia-Social and Behavioral Sciences, 2016, 219: 299-306.

[9] Ajitabh, A. and Momaya, Kirankumar S., Competitiveness of Firms: Review of Theory, Frameworks and Models (May 9, 2003). Singapore Management Review, Vol 26, No. 1, 2004, p. 45-61.

[10] Bowman, Cliff, Véronique Ambrosini, Firm value creation and levels of strategy, Management Decision, Vol. 45 Iss 3, 2007, pp. 360 - 371

[11] Lauterman, Christian, The ambiguities of (social) value creation: towards an extended understanding of entrepreneurial value creation for society, Social Enterprise Journal, Vol. 9 Iss 2, 2013, pp. 184 - 202

[12] Vicenza, Maria, Ciasullo Orlando Troisi, Sustainable value creation in SMEs: a case study, The TQM Journal, Vol. 25 Iss , 2013 pp. 44 - 61

[13] Zubac, Angelina, Graham Hubbard Lester W. Johnson, The RBV and value creation: a managerial perspective, European Business Review, Vol. 22 Iss 5, 2010, pp. 515 - 538

[14] Tyl, Benjamin, Lizarralde, Allais, Local Value Creation and Eco-design : A new Paradigm, International Scientific Committee of the 7th Industrial Product-Service System Conference - PSS. Procedia CIRP 30, 2015, 155-160.

[15] Luqman, et.al., An empirical analysis of construction organisations' competitive strategies and performance", Built Environment Project and Asset Management, Vol. 5 Iss 4, 2015, pp. 417 - 431

[16] Attila Chikán, National and firm competitiveness: a general research model", Competitiveness Review: An International Business Journal, Vol. 18 Iss: 1/2,2008, pp.20 - 28Kotler, Philip, Kevin Lave Keller. (2016). Marketing Management 15e - Global Edition. USA: Pearson Education

[17] Craven, David W., Nigel F. Piercy. (2013). Strategic Marketing Tenth Edition. Singapore: McGraw-Hill.

[18] Windows, M., Os, M., When, C. P., Wei, Y., Yildirim, P., den Bulte, C., ... Accenture, No Title No Title. Uma ética para quantos? (Vol. XXXIII), 2014.

[19] Chew, D. a. S., Yan, S., \& Cheah, C. Y. J. Core capability and competitive strategy for construction SMEs in China. Chinese Management Studies, 2(3),2008, pp. 203-214.

[20] Doyle, Peter, Value-Based Marketing: Marketing Strategies for Corporate Growth and Shareholder Value. Chichester, England: John Wiley \& Sons, 2008.

[21] Pirson, M, Social entrepreneurs as the paragons of shared value creation? A critical perspective. Social Enterprise Journal, 8(1), 2012, pp. 31-48.

[22] Grace, D., \& Lo, J, Value creation : an internal customers 'perspective. Journal of Services Marketing, 29(6/7), 2015, pp. 560-570. http://doi.org/10.1108/JSM-09-2014-0311

[23] CK Prahalad Dan Ramaswamy , Venkat ( 2004 ). The Future Of Competition: Co ...(2009). New Wave Marketing, Gramedia Pustaka Utama

[24] B. Nwielaghi Michael dan E. Ogwo, Trade Sales Promotion Strategies and Marketing Performance in the Soft Drink Industries in Nigeria, 2013.

[25] Wibowo, L. A., Sos, S., Gaffar, V., \& Ak, S. E. Pembentukan Citra Taman Rekreasi Dki Jakarta Sebagai Green City Melalui Kualitas Penyampaian Jasa Dan Value Creation (Studi Pada Para Pengunjung Taman-Taman Rekreasi Di Dki Jakarta). 